\title{
集合住宅のバルコニー手摺りに FIELD MEASUREMENTS ON WIND 作用する風圧力に関する実測 FORCES ACTING ON BALCONY HANDRAILS
}

$\begin{array}{ll}\text { 岡崎充隆 }- \text { * } * 1 & \text { 山内豊英 }- \text { 谷池義人 } * 2 \\ \text { 谷口徹郎 }-44\end{array}$

キーワード :

実測，バルコニー手摺り，風圧力

Keywords:

Field measurement, Balcony handrail, Wind force

\section{Mitsutaka OKAZAKI - * 1 \\ Tetsurou TANIGUCHI $-* 3$}

Toyohide YAMAUCHI $-* 2$

This report shows the wind force characteristics which acts on balcony handrails of condominium under natural wind condition. As the results, the large wind pressure force acts on the balcony handrails at the corner part, and uniformly distributed of the height direction. The mean wind force coefficient which acts on balcony handrails showed that it was possible to evaluate at the inclination of the straight line which envelops peak wind pressure force to the maximum dynamic pressure. It proposed the evaluation method of peak wind force coefficient of the balcony handrail which considered a phenomenon under the natural-wind for the design.

\section{1. はじめに}

集合住宅等のバルコニー手摺りには、コンクリート手摺りやアル ミ製枠に縦格子、横ルーバー、ガラススクリーン等を取り付けた手 摺りなどがあるが、充実率が高くなると、風荷重による検討が重要 になる。しかし、現行の建築基準法等の規基準には、バルコニー手 摺りに関する荷重算定方法は示されておらず、設計者の判断に委补 られている。

これまでに筆者らは、板状中高層集合住宅および角柱形状の超高 層集合住宅を対象として、縮尺 $1 / 200 〜 1 / 300$ の縮尺模型を用いた風 洞実験を行い、バルコニー手摺に作用する風荷重に関する報告を行

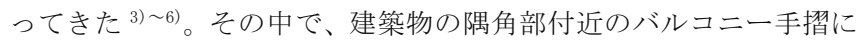
は、内側から外側への極めて大きな風力が作用することを示した。 一方、建物中央部付近では、手摺りの内側と外側に発生する圧力は 正の相関が高く相殺するため、バルコニー手摺に作用する風力は極 めて小さくなることを示した。さらに、細部の風力分布を評価する とともに、自然風の風向・風速変動等の非定常な性状による影響に ついて検証を行うために、角柱形状の超高層集合住宅 (辺長比 $1: 1$ : 5）をモデル化した縮尺 $1 / 30$ の実測模型を用いて野外実測を行い、

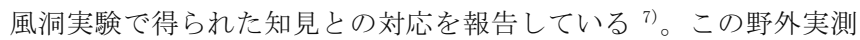
の結果では、バルコニー手摺りに作用するピーク風力は、瞬間速度 圧によって評価できる可能性について示した。

本報告は、板状中高層集合住宅(辺長比 3:1:4) そモデル化した縮 尺 $1 / 20$ の実測模型を用いた、バルコニー手摺りに作用する風力の野 外実測に基づくものである。本報告では、まずバルコニー手摺りに 作用ピーク風力と、基準風速から算定した瞬間速度圧の関係につい
て示す。また、瞬間速度圧に対応して発生するピーク風力について、 物理的な考察を行う。さらに、この考察に基づき、設計荷重を評価 する方法の提案を行う。

\section{2. 野外実測概要}

野外実測は、大阪の舞洲にある大阪市立大学而風構造実験所において行 なった。図 1 に実験所の配置図を示す。実験所は、西側および南側が大阪 湾に面しているが、北北東から南南東側は高さ $7 \sim 8 \mathrm{~m}$ の高木植栽が並んで いる。このため、東寄りの風については、風速值が低く乱れも極めて大き 、気流となる。従って、実測では対象とする風向を西寄りの風（風向南〜 西〜北）に絞り、実測模型の圧力測定孔も、これらの風向を対象として配 置している。図 2 およ゙図 3 に野外実測に用いた実測模型の立面図、平面 図および圧力測定孔の平面配置詳細図を、写真 1 に実測模型外観を示す。 実測模型縮尺は $1 / 20$ で、 7 スパン 15 階建て高層集合住宅（軒高約 $46 \mathrm{~m} ）$ をモデル化しており、模型辺長比はB:D:H=2, 400 mm:600mm:2, 300 mm である。 この供試体には、実スケールで $1.6 \mathrm{~m}$ に相当する出幅 $80 \mathrm{~mm}$ のバルコニーを 北面、西面および南面の 3 面に配置し、そのうち、15 階（レベル 1 ）、12 階（レベル 2）、7 階（レベル 3）のバルコニーには、図 3 に示すように バルコニー手摺りの内部側および外部側に圧力測定孔を設けている。実測 における基準風速は、図 1 に示寸観測用鉄塔に設置した超音波風速計（図 1 の Reference Point）により計測した。なお、実測模型の中心から超音 波風速計は、北西側に約 $15 \mathrm{~m}$ 離れており、また、実測模型の頂部高さが G. L. +2, 350mm であるのに対し、風速計の設置高さは G. L. +2, 500mm で若干 異なる。この超音波風速計は、風向北を $0^{\circ}$ として設定しており、本実測 で対象としている風向は、風向角 $180^{\circ}$ (風向南) から風向角 $360^{\circ}$ (風
1 (株)長谷工コーポレーション技術研究所

（干 343-0822＼cjkstart埼玉県越谷市西方 2968）

浅沼組技術研究所

"3 大阪市立大学大学院工学研究科 建築防災分野 准教授.工博

大阪市立大学大学院工学研究科 建築防災分野 教授・工博

\footnotetext{
Technical Research Institute, Haseko Corporation

Technical Research Institute, Asanuma Corporation

Assoc. Prof., Osaka City Univ., Dr. Eng.

Prof., Osaka City Univ., Dr. Eng.
} 
向北）となる。(図3 参照) バルコニー手摺りおよび建物壁面に作用する 風圧力は、内径 $5 \mathrm{~mm}$ のシリコンチューブを介して、供試体内部に設置した 圧力センサーに伝達され、敷地内マンホール（図 1 の Atmospheric Pressure）の圧力を基淮静圧とした差圧を測定した。風向風速データおよ び各圧力測定点での圧力データは、サンプリング周波数 $50 \mathrm{~Hz}$ で、実時間 換算した平均化時間は約 $0.12 \mathrm{sec}$ となる。また、解析時にはチューブの伝 達特性を考慮し補正 ${ }^{11}$ を施した。なお、1 回の計測時間は約 22 分（デー 夕数 65536 個) とした。

\section{3. 実測結果}

本報告では 2007 年 3 月から 2008 年 3 月に測定された、それぞれ 約 22 分間、1 155 個の結果を用いている。実構造物との縮尺を考えた 場合、距離縮尺 $1 / 20$ 、風速縮尺 $1 / 3$ とすると、時間縮尺は $1 / 6$ 前後 となる。本報では、極端な風向変動および風速変動による影響を避 けるため、評価時間を約 $40 \mathrm{sec}$ (データ個数 2048、実時間で約 $180 \mathrm{sec}$ ) を基本として解析を行うこととした。また、風洞実験による研究結 果 $\left.\left.{ }^{3)}, 4\right), 5\right), 6$ より、バルコニー手摺りで最も風力が大きくなるのは、

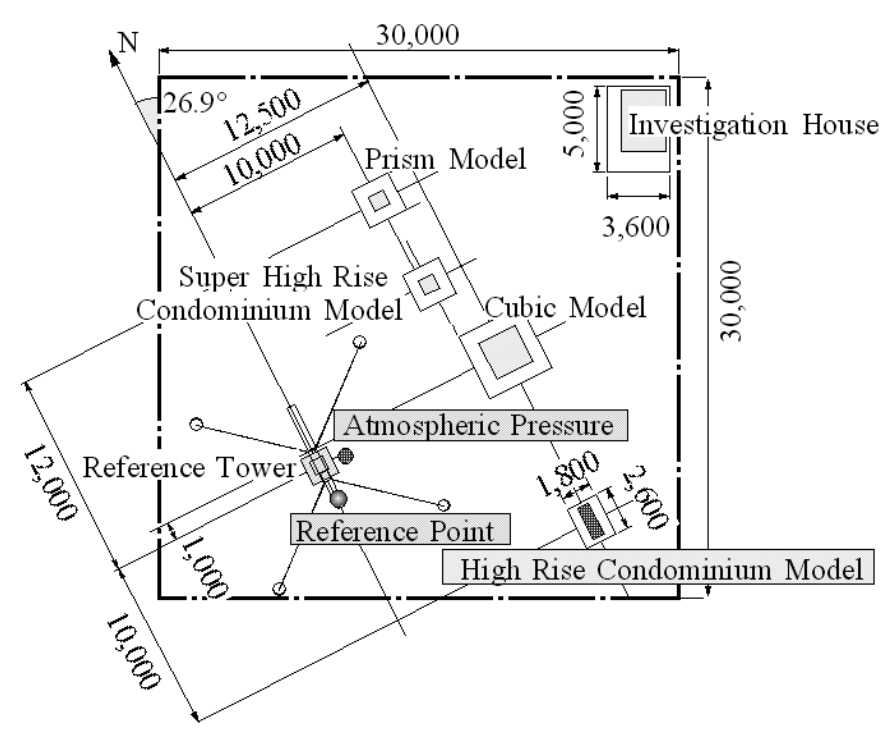

図 1 大阪市立大学耐風構造実験所配置図

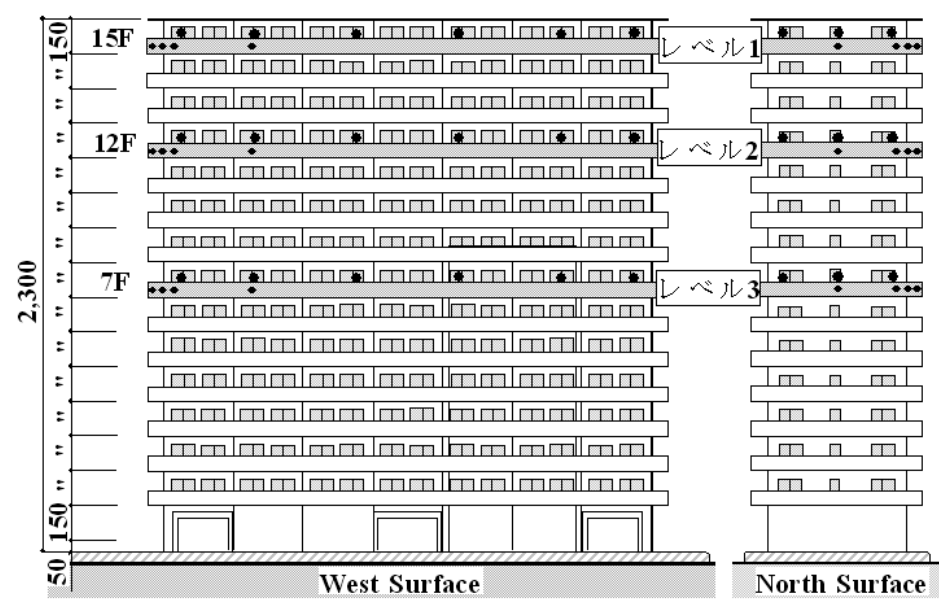

図 2 実測供試体立面図
図 3 の B2 B B の隅角部付近であり、特に辺長比が大きい場合は、短辺側 の $\mathrm{B} 2$, B3, B4 の風力が、風が長辺側に正対する時 (風向角 $270^{\circ}$ ) に、最も 大きくなる結果が得られている。さらに、風洞実験で長辺側の $\mathrm{B} 5, \mathrm{~B} 6$ がピ 一ク值を示寸風向は風向角 $360^{\circ}$ 前後であったが、今回の実測データでは $360^{\circ}$ 前後のデータが極めて少ないことから、本報告においてはB4におけ る結果を中心に報告することとする。なお、以降に示寸風力係数の符号は、 外側から内側に向かう風力を正として表示寸ることとする。

\section{1 自然風の性状}

図 4 および図 5 は基準風速の平均風速および乱れ強さと風向の関係を 示している。なお、平均風速が小さい場合には、風速および風向の変動が 極めて大きくなっており、評価時間の平均風速が $4 \mathrm{~m} / \mathrm{sec}$ 以下のデータは 解析対象から除外することとした。また、接近流の乱れ強さは $20 \sim 40 \%$ 程 度に分布しており、建築物荷重指針に従って想定建物高さでの乱れ強さを 算定した場合、地表面粗度区分IIIで 20\%以下であることを考えると、本実 測結果は乱れ強さが比較的大きな状況での結果と考えられる。また、図 6 は評価時間内での接近流のガストファクターを示している。全てのデータ

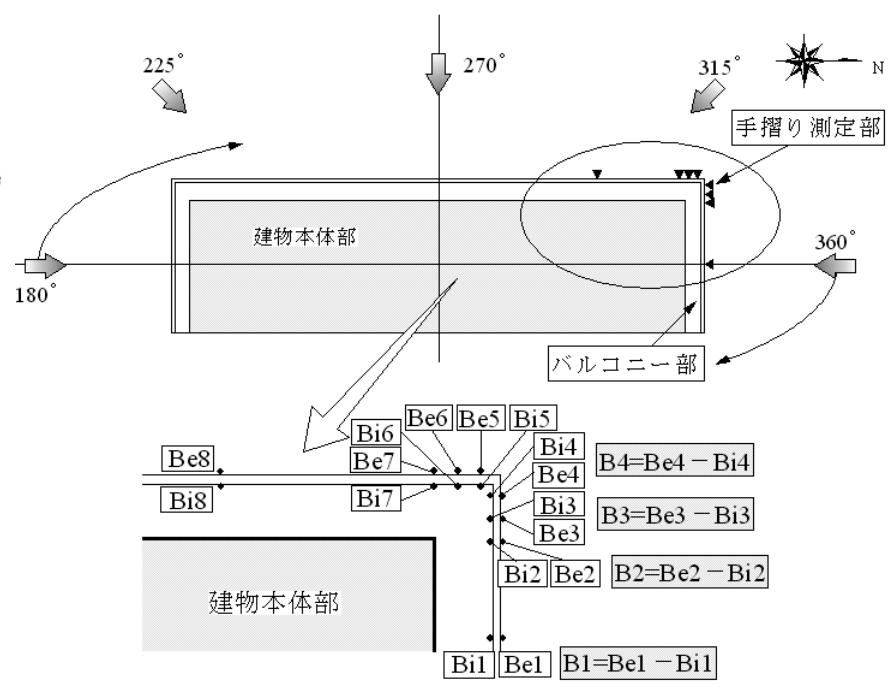

図3 実測供試体平面図兼測定点配置図

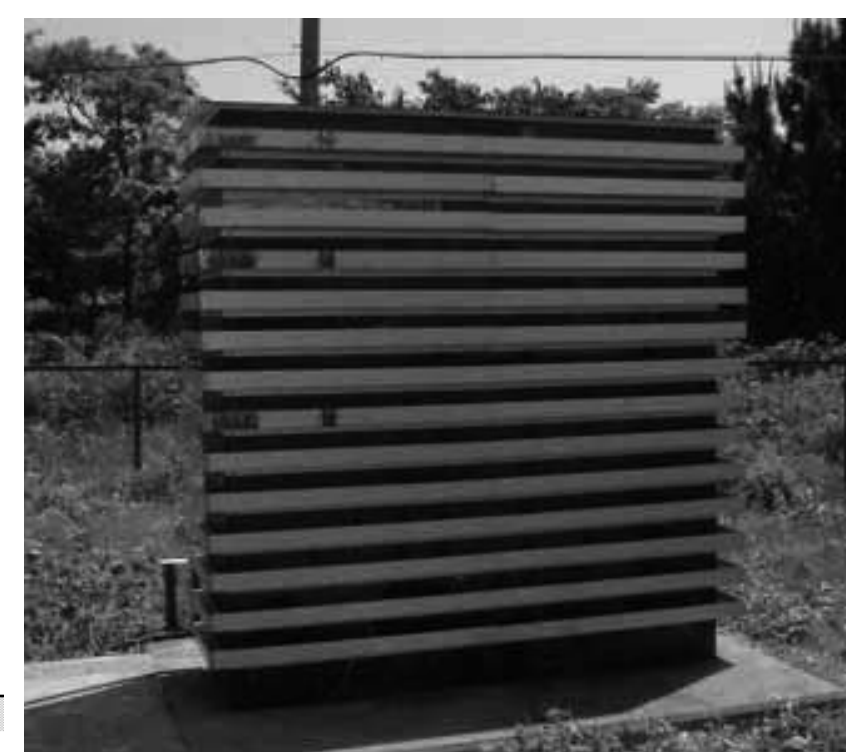

写真 1 供試体外観写真 
で 1.5 以上、最大で 2.8 程度を示している。なお、比較対照している風洞 実験 ${ }^{3)}$ では、建物頂部高さでの乱れ強さは約 14\%、突風率は 1.35 前後であ った。

\section{2 解析対象高さ}

風洞実験では、バルコニーに作用する風力の高さ方向分布は、平均風 力、ピーク風力ともほぼ一様に分布し、その中でも建物高さの 0.8 付近で 絶対值が若干大きくなる結果を得ている。図 7 および図 8 はバルコニー手 䅛りの B4 部に作用する平均風力について、レベル 1 とレベル 2 およびレ ベル 3 とレベル 2 を比較したものである。レベル間の風力比は、ほぼ 1.0 に近い值を示しており、B4 部に作用する風力の高さ方向分布は、規基準に 示されている建物隅角部の負のピーク風圧係数と同様に、高さ方向に一様 な分布と考えて良いと考えられる。一方で、風力比の勾配はレベル $1 \sim 3$ の中で、無次元高さ 0.8 となるレベル 2 で若干大きくなる傾向を示してお り、以降の解析結果にはレベル 2 の実測結果を中心に示すこととする。

\section{3 平均風力係数の分布}

図 9 はレベル 2 の B4 部での、基準風速の平均值に基づく平均風力係数 と風向の関係を示す。図中には同形状の実験模型を用いて行った、風洞実 験における平均風力係数の值(Wind Tunne1)を示している。風洞実験では 平均風力係数の最小值は風向角 $270^{\circ}$ で発生し、その值は-2.8であったが、 実測でも $270^{\circ}$ 付近で平均風力係数が-3.0 となっており、風洞実験とほぼ 同じ值を示している。また、野外実測における平均風力係数は、風洞実験 結果を下限として分布している。図 10 はレベル 2 の他の測定ポイントを 含めて、全風向の実測結果より求めた平均風力係数の最小值を平面図上に プロットしたものであり、比較対照として風洞実験における平均風力係数 の最小值も示している。風洞実験結果では実験模型作成段階での物理的な 制約から測定点間隔が広くなっているが、実測での短辺部 B1〜B4 の平均 風力係数の最小值は、風洞実験に近い值を示していることが分かる。一方、 長辺部 B5〜B8 については、風洞実験の方が絶対值は大きな值を示してい るが、 $\mathrm{B} 5 \sim \mathrm{B} 8$ で平均風力係数が最小值を示すのは、風向角は $360^{\circ}$ 前後に 相当し、実測では風向角 $360^{\circ}$ 付近のデータがほとんど取れていない事が、 大きな主な要因であると考えられる。

\section{3 ピーク風力係数}

図 11 はレベル 2、B4 部での、ピーク風力係数の風向による変化 を示している。風洞実験ではピーク風力係数の最小值は-4. 2 程度で

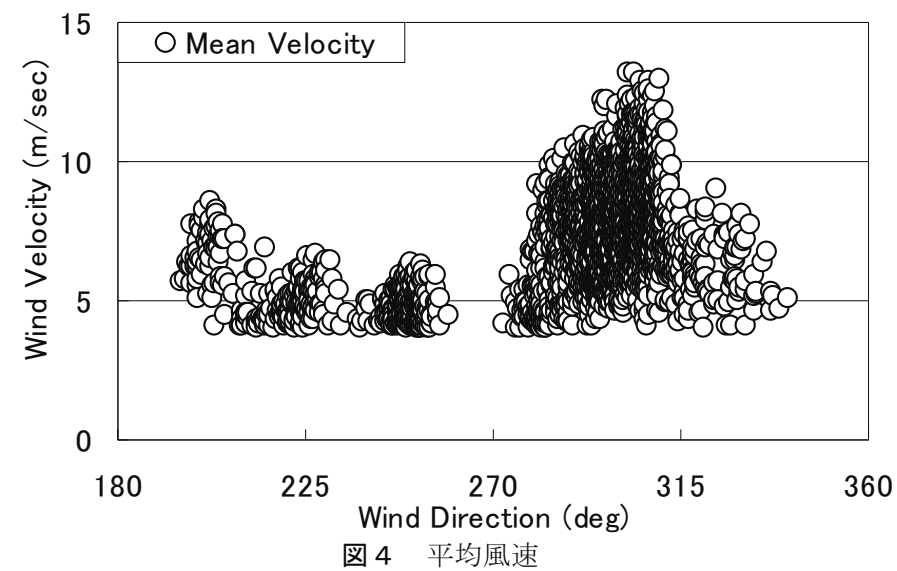

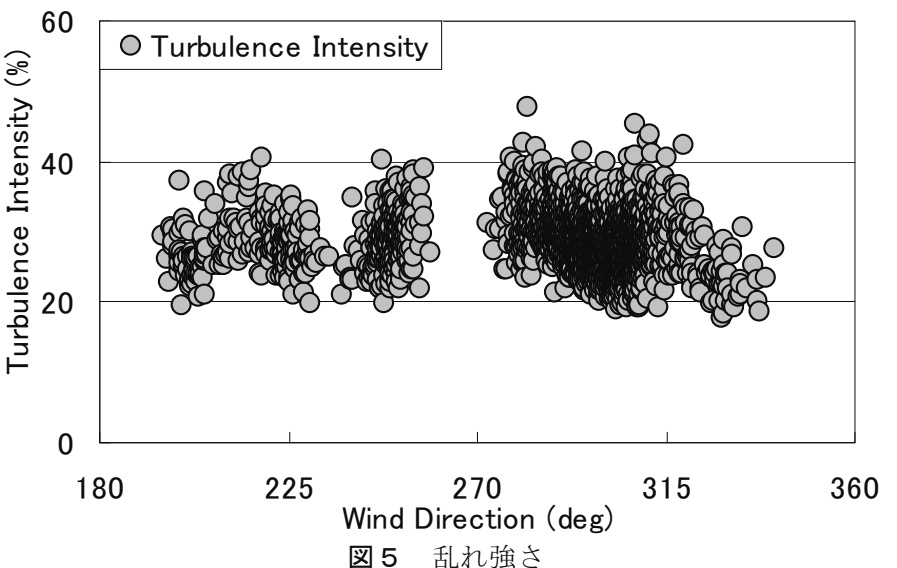

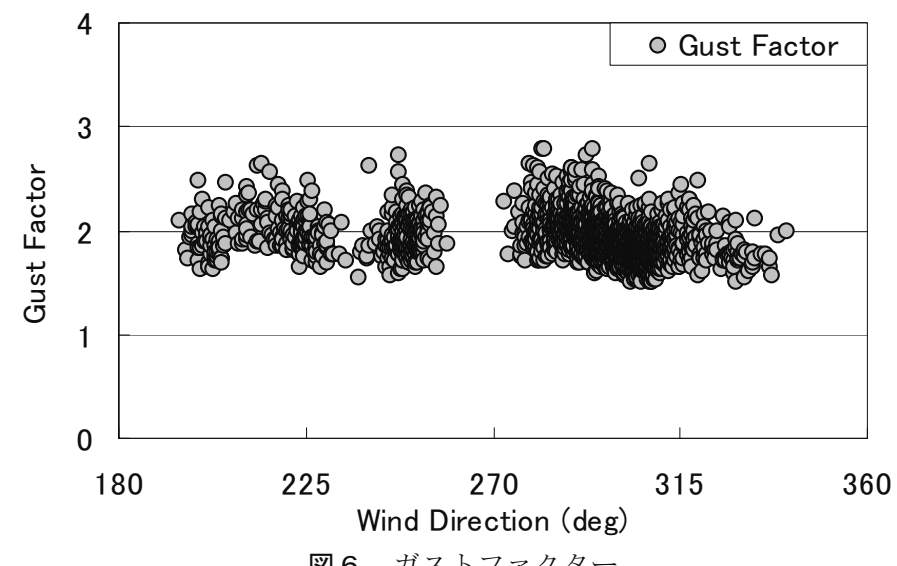

図 6 ガストファクター

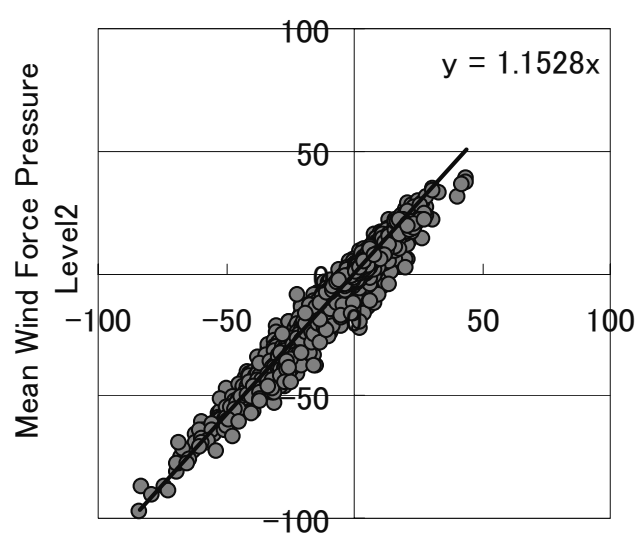

Mean Wind Force Pressure Level1

図 7 B4 部におけるレベル 2 とレベル 1 のピーク風力比

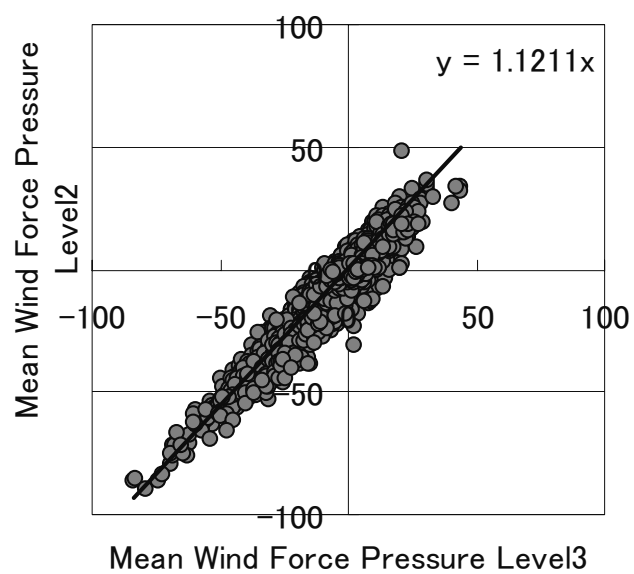

図 8 B 4 部におけるレベル 3 とレベル 1 のピーク風力比 
あったが、実測ではピーク風力係数の最小值は-15 近くとなった。 図中には風洞実験でのピーク風力係数を、併せて示している。 このように自然風中における実測で、ピーク風力係数が大きくなる 要因として、風向および風速変動が、風洞実験と比較して大きいこ とが挙げられる。つまり、接近流の平均風速が低い值であっても、 短時間に突風が発生した時、実測模型には瞬間的に大きな風力が作 用する場合があることになる。この場合、平均速度圧でピーク風力 を除したピーク風力係数は極めて大きな值となる。一方で、図 11 からも解るように、データの中にはピーク風力係数が、風洞実験結 果よりも絶対值が小さい場合も見られる。この場合、接近流の平均 風速に見合った瞬間風力が発生していないことになり、風速および 風向変動が大きい事が、必ずしもピーク風力係数の増加につながら ないことを示している。

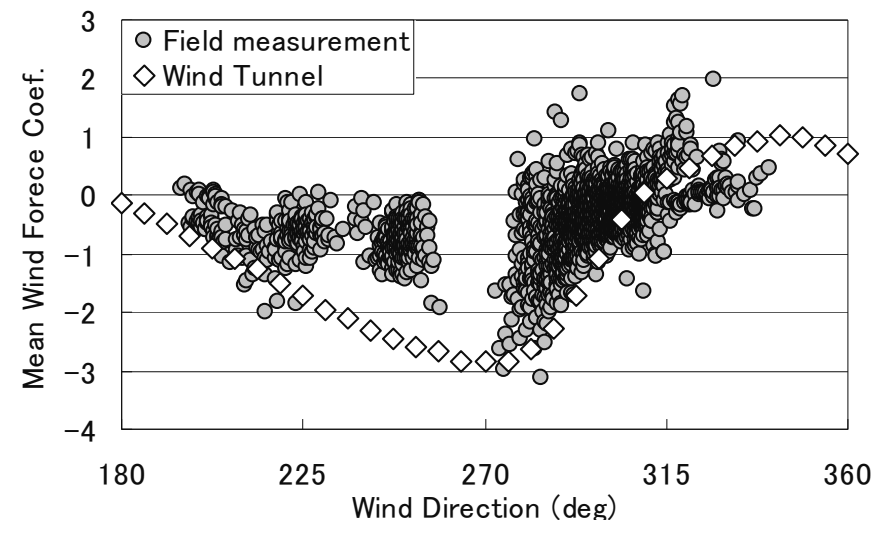

図 9 平均風力係数の風向による変化（B4 レベル 2)

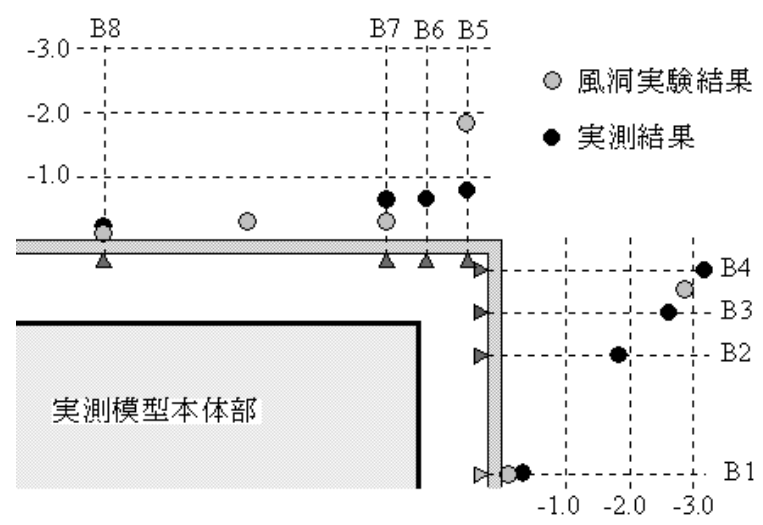

図 10 平均風力係数の平面分布（レベル 2)

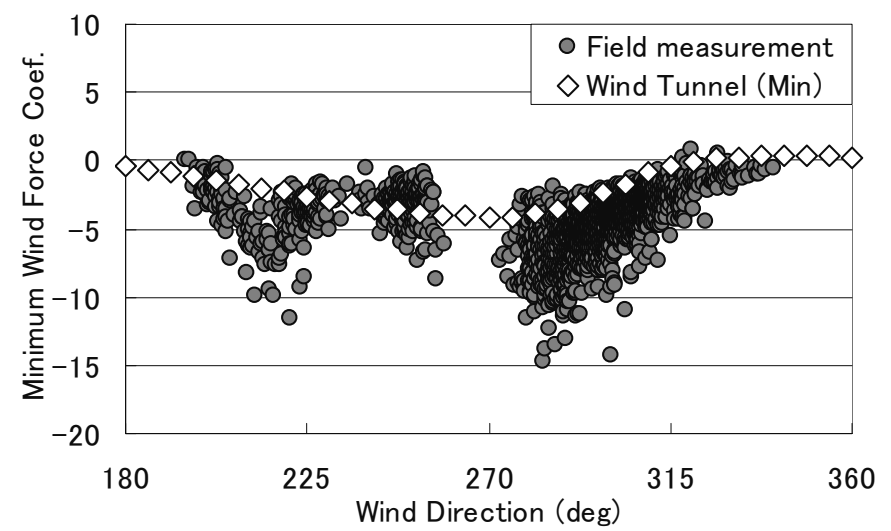

図 11 ピーク風力係数の風向による変化（B4 レベル 2)

\section{4 最大瞬間速度圧で除したピーク風力係数}

図 11 に示したように、実測結果の解析において、ピーク風圧力 を平均速度圧で除したピーク風力係数は極めて大きな值となる場合 があり、この結果をそのまま実務設計に用いることは、過大評価に なると考えられる。筆者らは、角柱形状の超高層集合住宅を対象と した野外実測に関する報告 ${ }^{7)}$ において、ピーク風圧力は評価時間内 の最大瞬間速度圧で除することで、平均風力係数に近い值となるこ とを示している。また、河井ら ${ }^{12)}$ は、ダブルスキンファサードの実 測結果で、同様な解析方法示している。そこで本報でも、ピーク風 圧力と最大瞬間速度圧の関係を見ることとした。

図 12 は評価時間内での最大瞬間速度圧とバルコニー手摺り B4 部に発生するピーク風力の関係を示したものである。図では多くの データが得られた風向角 $285 \pm 15^{\circ}$ および風向角 $300 \pm 15^{\circ}$ につい て示しており、a)，b)，c）はそれぞれ評価時間 $40 \mathrm{sec}, 80 \mathrm{sec}, 120 \mathrm{sec}$ としたものである。図中の実線は風洞実験での平均風力係数を勾配
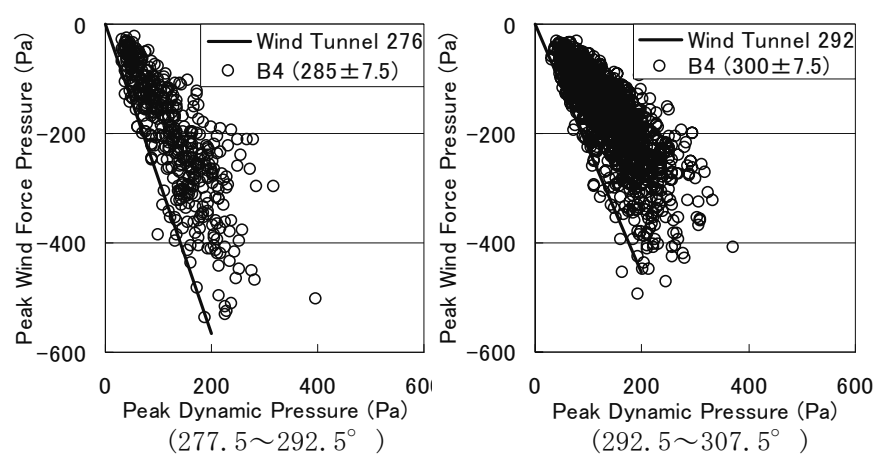

a) 評価時間 $40 \mathrm{sec}$

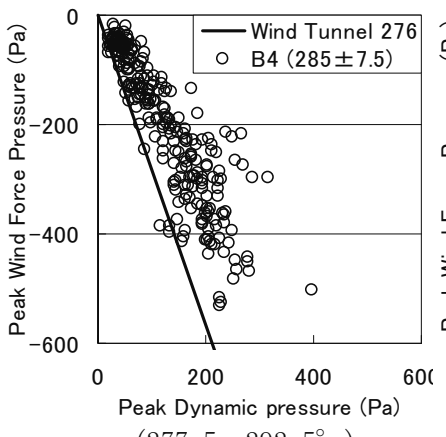

$\left(277.5 \sim 292.5^{\circ}\right)$

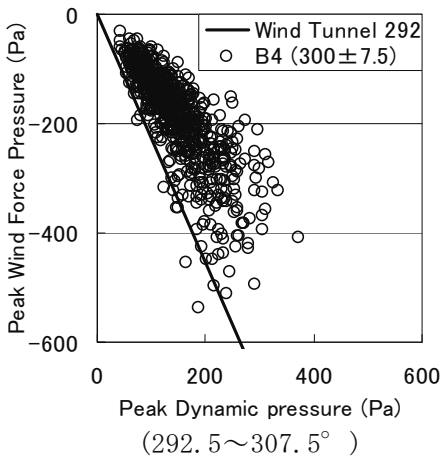

$\left(292.5 \sim 307.5^{\circ}\right)$ b）評価時間 $80 \mathrm{sec}$

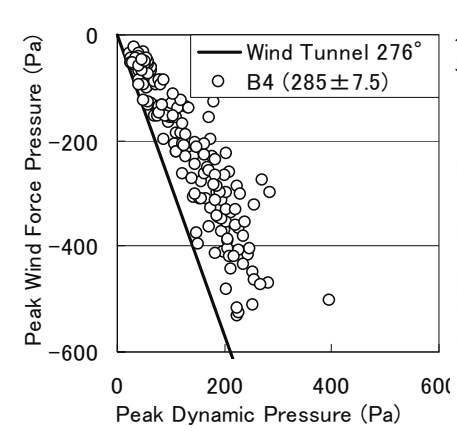

(277. 5 292. $5^{\circ}$ )

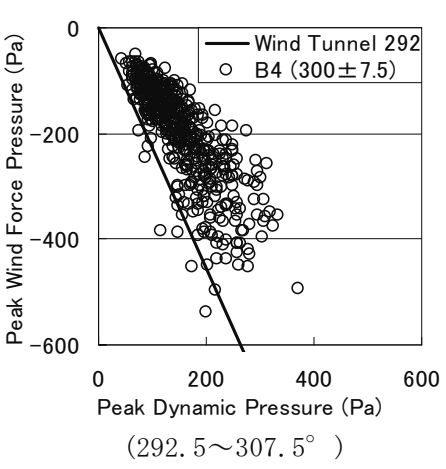

$\left(292.5 \sim 307.5^{\circ}\right)$ c) 評価時間 $120 \mathrm{sec}$

図 12 最大速度圧とピーク風圧力の関係 
とする直線である。評価時間を長くとることで、実測データのばら つきは少なくなり、それぞれのデータが風洞実験の平均風力係数を 下限として分布する傾向が見られる。そこで、この理由について考 察する事とする。

\section{5 風程を用いた考察}

桂 ${ }^{9)}$ は、準定常的な圧力変動が発生する条件として、対象とする 部位に応じた流形形成長さと、流路変化率が小さくなることを挙げ ている。流形形成長さについては、対象部位によって異なり、特に よどみ点付近では流形形成長さが最も短く、対象模型の背面では長 くなるとしている。図 14 は風速変動から算定した基準速度圧の変 動、実測模型のバルコニー手摺り B4 部の風力変動および風向変動の グラフであり、横軸には風速データから、式(1)より算定した風程 $S$ を取っている。

$$
s=\int_{0}^{t} V(t) d t
$$

なお、図 14 で速度圧変動と風力変動との対応では、接近流の測 定を行った風速計位置と実測模型との水平距離で $15 \mathrm{~m}$ 程度離れてい ることから、風程においても距離差が発生すると考えた。基準速度 圧の変動では、大きな速度圧が数回生じている。これに対し、手摺 りの風力を見ると、まず風程の短い $\mathrm{A}$ 部では速度圧の変動に対応す る風力の降下が見られない。また、 $\mathrm{B}$ 部では風程がある程度確保さ れているが、 $\mathrm{A}$ と同様に風力の降下は見られない。これは、この時 間帯における風向の変動が大きかったためであると考えられる。一 方、C 部では風程がある程度確保されているのと同時に、風向も比 較的安定しており、速度圧に追従する風力の降下が見られる。本研 究で対象としている、バルコニー手摺りの風力については、バルコ ニーの外部側に作用する風圧力と、内部側の風圧力が関係するため、 単純に流形が形成する必要条件を示すことは、困難であると考えら れる。しかし、評価時間を長くとることで、この評価時間内に流形 を形成させる条件を満たした突風が含まれる可能性が高くなり、こ の時バルコニー手摺りには瞬間速度圧に対応したピーク風力が準定 常的に生じるのではないかと考えられる。

\section{6 設計荷重算定に関する考察}

評価時間内に、流形が形成される状態が発生寸れば、バルコニー 手摺りには瞬間速度圧に対応したピーク風圧力が作用し、この時の 最大瞬間速度圧とピーク風圧力の比は風洞実験で得られる平均風力 係数に近い值をとると考えられる。野外実測では接近流の風速およ び風向変動により、得られたデータにはばらつきが発生するが、流 形が形成された状態では準定常状態に近くなり、瞬間速度圧に比例 したピーク風力が発生すると考えれば、最大瞬間速度圧に対して、 ピーク風力を包絡する直線の勾配が瞬間速度圧に基づく風力係数に なると考えられる。このことは、非定常な現象を含んだ実構造物に 対して設計用風荷重を導く一つの方向性を示していると考えられる 図 15 には風向角 $277.5^{\circ} \sim 292.5^{\circ}$ 、B2 部および B3 部評価時間 $40 \mathrm{sec}, 120 \mathrm{sec}$ での、最大瞬間速度圧とピーク風力の関係を示してい る。なお、風洞実験では B3 および B2 部に対応する圧力測定孔が無 かったため、図中には、実測で得られた B 3 および B 2 におる、平 均風力係数の最小值を波線で示している。この図から他の測定点に
於いても、最大瞬間速度圧とピーク風圧力の比が、平均風力係数と ほぼ同じ值となることが分かる。前項までの実測結果より、設計用 風荷重は式 (2)のように、最大瞬間速度圧に平均風力係数を乗じて算 定することも可能であると考えられる。一方、現状の規基準では、 設計用風荷重を式(3)のように設計風速より求めた平均速度圧にピ 一ク風力係数を乗じて算定する方法が取られている。この算定式に 準じたピーク風力係数は、式(4)のように表すことが出来る。

$$
\begin{aligned}
& W=q_{\max } \times \bar{C} f \\
& q_{\max }: \text { 建物頂部の最大瞬間速度圧 }(\mathrm{Pa}) \\
& \overline{C f} \text { : 平均風力係数 } \\
& W=q_{\text {mean }} \times \hat{C} f \\
& q_{\text {mean }} \text { : 建物頂部の平均速度圧 }(\mathrm{Pa}) \\
& C \hat{f}: \text { : ピーク風力係数 } \\
& \hat{C} f=\bar{C} f \times q_{\max } / q_{\text {mean }}
\end{aligned}
$$

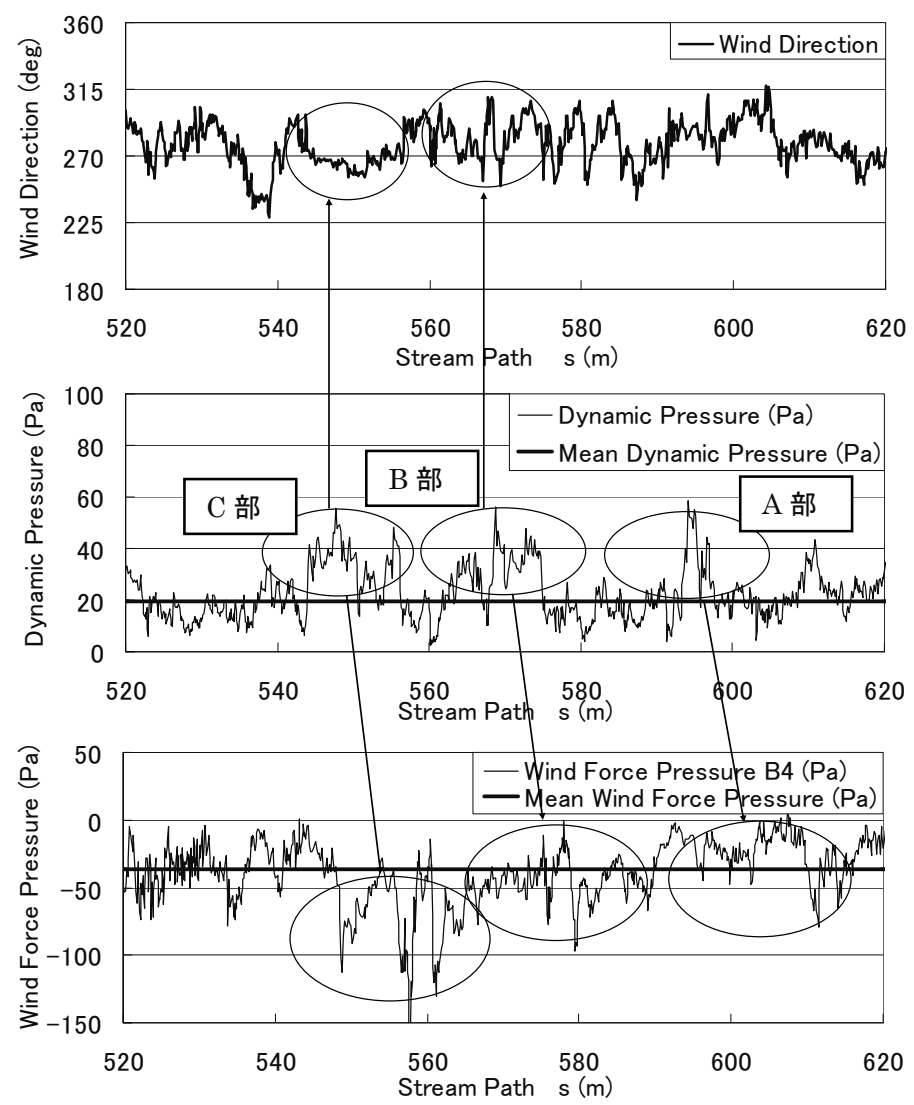

図 14 速度圧、B4 部風圧力および風向の風程波形

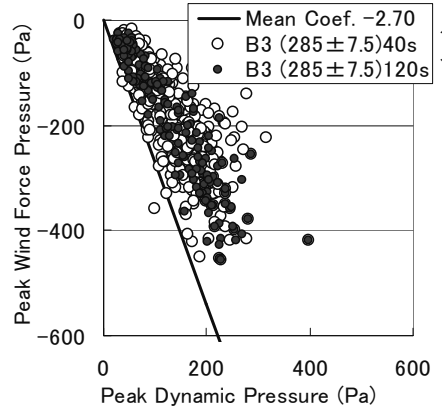

a) B2 部

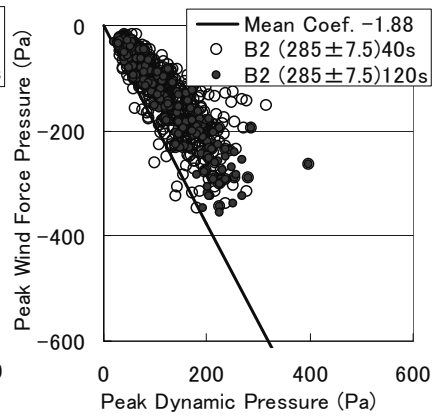

b) B3 部
図 15 ピーク風圧力と最大瞬間速度圧の関係 
式(4)から、風荷重算定用のピーク風力係数を算定する。例えば、バ ルコニー手摺り $\mathrm{B} 4$ 部では、平均風力係数の最小值は約 -2.8 であり、 平均速度圧と最大瞬間速度圧の比は、ガストファクターの 2 乗にな ることから、B4 部のピーク風力係数はガストファクターの值に対し て、図 16 の様なグラフで表すことができる。図中の○は風洞実験 での、ガストファクター 1.35 に対して最小ピーク風力係数が -4.2 を示している。さらに、バルコニー手摺り B4 部での実測データより、 風向角 $270 \pm 15^{\circ}$ の範囲で、ガストファクターと平均速度圧に基づ くピーク風力係数の值も併せて示している。式(4)に基づいてピーク 風力係数算定すると、風洞実験よりも大きな值を示す結果となるが、 非定常な自然風に対しては、評価できる值であると考える。

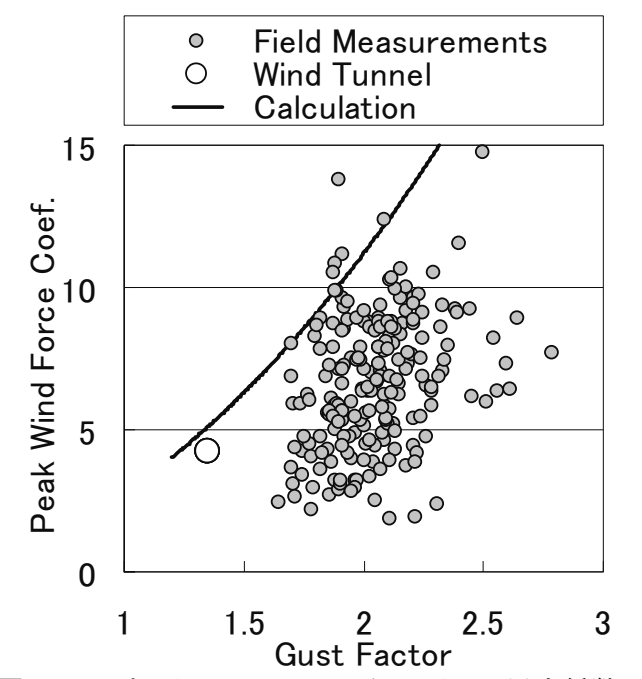

図 16 ガストファクターからのピーク風力係数予測值

\section{4. まとめ}

中高層建築物のバルコニー手摺りに作用寸る風力に関する縮尺 $1 / 20$ 実測模型を用いた野外実測を通して、以下の知見が得られた。

1）建築物の隅角部では、バルコニー手摺に大きな負の風圧力（内 部側から外部側に働く風圧力）が作用し、その平均風力係数は 同形状の $1 / 200$ 模型を用いて行った風洞実験結果に近い值をと ることを確認した。

2）実測結果より算定したバルコニー隅角部におけるピーク風力 係数は、風洞実験の場合と同様に、高さ方向にほぼ一様に分布 する。

3）バルコニー手摺に作用する風力は、建物周りの流形が形成され た状態で最も強くなり、その值は瞬間速度圧に比例する形で、 準定常的に評価できることを示した。

4）上に示した自然風の下での現象を考慮した、バルコニー手摺り の設計用ピーク風力係数の評価式を提案した。

\section{参考文献}

1) 魏然、義江龍一郎、丸山勇祐 : 高層建物のパネル手すりに作用するピーク 風圧、日本建築学会大会学術講演梗概集 B1、pp. 201-202、2000.

2)上林正、芦沢知樹：2 階建て集合住宅に付属するバルコニーのピーク風圧 係数、日本建築学会大会学術講演梗概集 B1、pp. 131-132、2001.

3) 森脇一樹、岡崎充隆、谷池義人、谷口徹郎 : 集合住宅の手摺りに加わる風 圧力の性状、日本建築学会大会学術講演梗概集 B1、pp. 179-180、2003
4) 山内豊英、谷池義人、谷口徹郎 : バルコニーを有する建築物の風荷重に関 する研究 その 1 風洞実験および結果の概要、日本建築学会大会学術講演梗 概集 B1、pp. 93-94、2004

5) 山内豊英、谷池義人、谷口徹郎 : バルコニーを有する建築物の風荷重に関 する研究その 2 バルコニー手暞に作用する風荷重の評価、日本建築学会大 会学術講演梗概集 B1、pp. 191-192、2005

6) 山内豊英、岡崎充隆、谷口徹郎、谷池義人 : 建築物のバルコニー手替に作 用する風荷重、第 19 回風工学シンポジウム論文集、pp. 383-388、2006 7) 山内豊英、岡崎充隆、谷口徹郎、谷池義人：野外実験による建築物バルコ ニー手替のピーク風力係数、第 20 回風工学シンポジウム論文集、pp. 383-388、 2008

8) 高森浩次、西村宏昭：凹凸のある建物の風圧分布、日本建築学会大会学術 講演梗概集 B1、pp. 1061-1062、1993

9) 桂順治 : 突風によって模型建物に生じる流形の形成について、日本建築学 会構造系論文報告集 第 451 号 p. 65-78 1993

10) 山縣誠一郎、前田潤慈: 瞬間風速の評価時間がガストファクターに及ぼす 影響に関寸る二、三の考察、日本建築学会大会学術講演梗概集 B1、pp. 135-136、 1996

11) Holmes, J. D. , Lewis, R. E. : Optimization of Dynamic-Pressure-Measurement Systems. I. Single Point Measurements, Journal of Wind Engineering and Industrial Aerodynamics, 25, pp. 249-273, 1987

12) 河井宏允、西村宏昭、鈴木雅靖、大浦豊 : ダブルスキンファサードに作用 する風圧力に関する実大測定について、第 20 回風工学シンポジウム論文集、 pp403-408、2008

[2009 年 2 月 20 日原稿受理 2009 年 4 月 6 日採用決定］ 